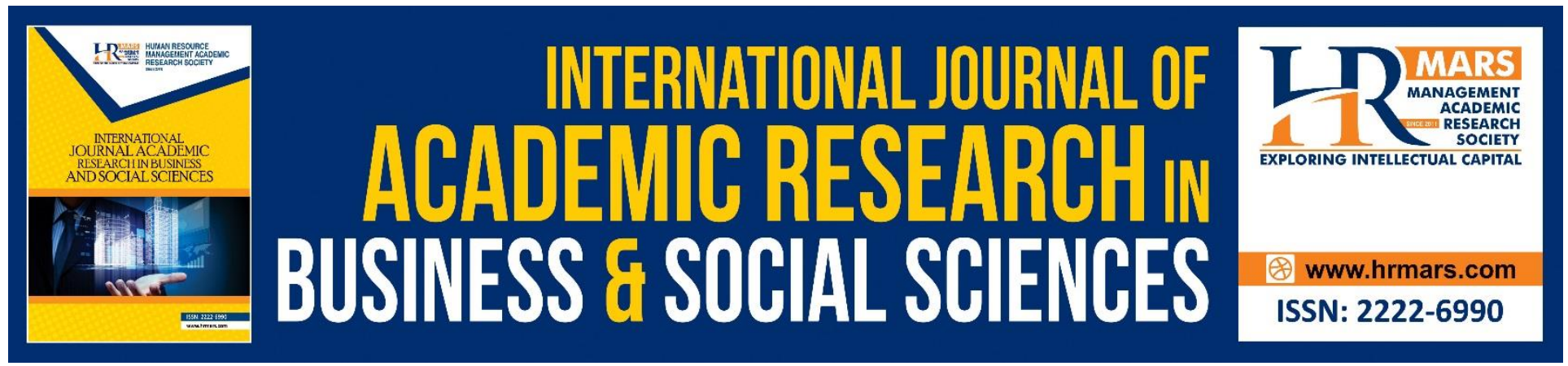

\title{
A Mediating Effect of Risk Perception on Factors Influencing Tourist Intention to Travel: A Conceptual Framework
}

\begin{abstract}
Ahmad Shukri Yazid, Mohd Yuhafidz Mohd Yusof, Norfadzilah Rashid, Puspa Liza Ghazali, Fauzilah Salleh, Mohd Sadad Mahmod and Suraya Mahmood
\end{abstract}

To Link this Article: http://dx.doi.org/10.6007/IJARBSS/v8-i11/5166

DOI: $10.6007 /$ IJARBSS/v8-i11/5166

Received: 18 Oct 2018, Revised: 21 Nov 2018, Accepted: 06 Dec 2018

Published Online: 07 Dec 2018

In-Text Citation: (Yazid et al., 2018)

To Cite this Article: Yazid, A. S., Yusof, M. Y. M., Rashid, N., Ghazali, P. L., Salleh, F., Mahmod, M. S., \& Mahmood, S. (2018). A Mediating Effect of Risk Perception on Factors Influencing Tourist Intention to Travel: A Conceptual Framework. International Journal of Academic Research in Business and Social Sciences, 8(11), 1246-1255.

\section{Copyright: (C) 2018 The Author(s)}

Published by Human Resource Management Academic Research Society (www.hrmars.com)

This article is published under the Creative Commons Attribution (CC BY 4.0) license. Anyone may reproduce, distribute, translate and create derivative works of this article (for both commercial and non-commercial purposes), subject to full attribution to the original publication and authors. The full terms of this license may be seen

at: http://creativecommons.org/licences/by/4.0/legalcode

Vol. 8, No. 11, 2018, Pg. 1246 - 1255

http://hrmars.com/index.php/pages/detail/IJARBSS

JOURNAL HOMEPAGE

Full Terms \& Conditions of access and use can be found at http://hrmars.com/index.php/pages/detail/publication-ethics 


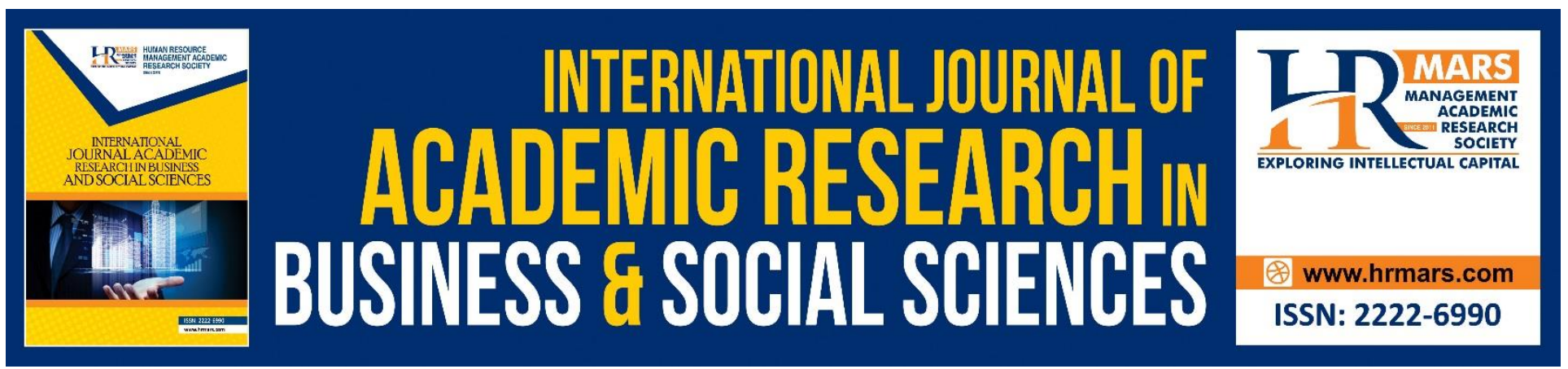

\title{
A Mediating Effect of Risk Perception on Factors Influencing Tourist Intention to Travel: A Conceptual Framework
}

\author{
${ }^{1}$ Ahmad Shukri Yazid, ${ }^{*}$ Mohd Yuhafidz Mohd Yusof, ${ }^{3}$ Norfadzilah \\ Rashid, ${ }^{4}$ Puspa Liza Ghazali, ${ }^{5}$ Fauzilah Salleh, ${ }^{6}$ Mohd Sadad \\ Mahmod and ${ }^{7}$ Suraya Mahmood \\ ${ }^{1}$ Faculty of Economics and Management Sciences, Gong Badak Campus, 21300 Kuala Terengganu, \\ Malaysia
}

${ }^{2}$ Research Institute for Islamic Products and Civilization (INSPIRE), Gong Badak Campus, 21300 Kuala

Terengganu, Malaysia

Corresponding Author: yuapis82@yahoo.com

\begin{abstract}
Over the decade, tourism has experienced major expansion and diversification, thus transforming into one of the largest, fastest growing economic sectors in the world. The tourism industry becomes the largest source of employment and foreign revenue for a number of countries; therefore most of the countries become relatively dependent on the industry and similar thing goes to Malaysia's tourism industry. Malaysia's tourism market is growing including both inbound arrivals and outbound departures throughout past several years and expected to grow on each following year. However, it cannot be deny that tourism industry unable to develop in places that are perceived as dangerous especially to the tourists, which in turn affect the number of tourist arrival to Malaysia. Since tourism industry is very significant to Malaysia's economy, there is a need to have a comprehensive research of risk perception in the Malaysian context. Thus, the main objective of this paper is to propose a conceptual framework that shows relationship between various factors (tourist past experiences, cultures, proximity, psychographics and demographic) in influencing intention to travel among international tourists while having risk perception as mediating variable that surface between independent and dependent variables.
\end{abstract}

Keywords: Tourists, Intention to Travel, Risk Perception

\section{INTRODUCTION}

Tourism industry has emerged as one of the most significant source of national income and career opportunities for most countries. The previous decades has shown that there is a sustainable growth 
of world tourism industry both as an activity and an industry. According to 2014 report by UNWTO, international tourist arrivals raised by $5 \%$ in 2013, reaching a record of 1087 million arrivals worldwide, compare to 2012 which recorded 1035 million of arrivals. Europe regions has led the growth in international travelling while, Asia and the Pacific recorded the fastest growth across all UNWTO regions, with a $6 \%$ increase in international arrivals. Africa stated an increase of $5 \%$, reaching 56 million of international tourists. In the Americas, international arrivals increased by $3 \%$ to 168 million, or an increase of five million. Meanwhile the Middle East has not yet succeeded in returning to growth.

\section{Tourism in Malaysia}

Malaysia's tourism industry is growing both inbound arrivals and outbound departures throughout past several years and it is expected to grow on each following year. Most arrivals to Malaysia are dominated by countries within the Asia Pacific region owing to the variety of travel connections and the relative affordability of regional travel. Forecasting by Business Monitor International (BMI) show that the number of visitors to Malaysia seem to have a healthy growth. Arrivals from other regions are also expected to increase, although these markets remain vulnerable to potential economic declines which could affect the arrivals. Tourism in Malaysia has become among a major contribution in national GDP, being the third biggest contributor to the country's economy after manufacturing and palm oil. The statistic indicates that tourism in Malaysia is expanding gradually. According to Malaysia Tourism statistics, the number of tourist arrival is increasing from 5.56 million tourists in 1998 to 25.03 million tourists in 2012. This indicates that tourism industry is very important sector and significant to Malaysia economy. Since it is essential to the growth of Malaysia economy, tourism industry must be performed, by which eliminating every probability of unfavorable events that might affect the number tourist arrival.

\section{PROBLEM STATEMENT}

Tourism cannot develop in places that are perceived as dangerous (Reisinger and Mavondo 2006). In tourism industry, there are risks that have to be considered. If the tourism industry is going to be prosperous, efforts to increase the industry's understanding of risk perception among tourists have to be made. Malaysia, which is located in South East Asian, has facing a number of challenges to its security in the 2010s, largely in the form of Islamist militancy, piracy and weak borders which can shift travel intention to other regions (Malaysia Tourism Report 2012). International issues such as the incident of missing MH370, MH17 shot down in Ukraine, invasion and tourist kidnapping in Sabah had become the major factor contributed to the dramatically decreasing number of international tourist to Malaysia. According to the Minister of Tourism and Culture, Datuk Seri Mohamed Nazri Abdul Aziz, the number of tourists from China has dropped in which there was one or two months dropped more than 30\% (Utusan Malaysia, November 2, 2014). The level of security and safety in Malaysia is rated as medium, but it cannot guarantee Malaysia as a pure safer place to visit. Several violent cases involving international tourist have been reported in local newspapers.

Since there is a lack of study of risk perception in Malaysia, there is a need to have such research since most of the previous studies have been done in other countries. It is believe that the research 
INTERNATIONAL JOURNAL OF ACADEMIC RESEARCH IN BUSINESS AND SOCIAL SCIENCES

Vol. 8, No. 11, Nov, 2018, E-ISSN: 2222-6990 @ 2018 HRMARS

on risk perception is important especially in contributing to sustainable growth in tourism industry since it helps tourist operators to manage business by considering unexpected event to minimize risks and thus maximize profit with providing a pleasure environment for tourists. And to tourists, understanding perception of risk is important especially in making better travel decision (minimizing risk) with the main purpose to enjoy travelling in Malaysia.

\section{RESEARCH OBJECTIVES}

1. To identify the effect of past experiences, cultures, proximity, psychographics and demographics factors on risk perception among international tourists.

2. To identify the effect of past experiences, cultures, proximity, psychographics and demographics factors on tourist intention to travel internationally.

3. To investigates the influence of risk perception as mediating variables in affecting tourist's intention to travel.

\section{LITERATURE REVIEWS}

Risk definition

Risk is defined as an exposure to certain threats or danger (Reisinger \& Mavondo 2005). Danger and threat might consist of natural disasters, health disease, political instability and terrorism attack. Risk in tourism manages to affect valuable assets of tourists, especially their life and their valuable items. Bauer (1960) has introduced the concepts of risk and uncertainty. Each consumer has different behaviors in purchasing and these behaviors involve risk because any action made by consumer will produce probability of unfavorable incident in which contributes the consequences which might be unpleasant consequences. Stone \& Gronhaug (1993) refers risk as a condition in which the number of possible events exceeds the number of events that will actually occur. The exceeding number of possible event shows that there is additional event that is unknown both to the tourism service operators and international tourist. The unknown future event is best explained by Kerzner (2001) which argue that unknown of possible future events may give a negative impact on the business. Without known of future event, it is difficult to estimate what kind of consequences faced by the tourism service operators and international tourist.

Perceived risk is mostly be defined as a subjectively determined expectation of a potential loss, in which a probability can be assigned to each possible outcome (Dholakia, 2001; Dowling \& Staelin, 1994; Murray \& Schlacter, 1990; Stone \& Gronhaug, 1993; Sweeney, Soutar, \& Johnson, 1999). Each tourist may perceive different levels of risk associated with the same outcome. Risk perception includes the process of assigning probability on each incident occurred in which, is a subjective assessment of the probability of a specified type of event and how concerned the person with the consequences (Torbjorn Rundmo 2004).

In consumer behavior, seven types of risks have been identified and how important the risk to the tourist depends on the particular situation (Brooker 1983; Cheron and Ritchie 1982; Jacoby and Kaplan 1972; Kaplan, Szybillo, and Jacoby 1974). The risks are equipment risk, financial risk, physical 
INTERNATIONAL JOURNAL OF ACADEMIC RESEARCH IN BUSINESS AND SOCIAL SCIENCES Vol. 8, No. 11, Nov, 2018, E-ISSN: 2222-6990 @ 2018 HRMARS

risk, psychological risk, satisfaction risk, social risk, and time risk. Each types of risk would give an impact on tourist decision to travel to particular destination.

\section{Factors influencing tourist intention to travel}

Many factors affecting tourists' intention to travel have been studied, including demographic factors, previous experience, culture, proximity, psychographics and perceptions of risks (Mazursky 1989; Sonmez, S. F., \& Graefe, A. R. 1998, 1998a; O'Leary and Deegan, 2003; Kozak et al., 2007; Floyd, M., \& Pennington-Gray, L. (2004); Lepp \& Gibson, 2003; Sackett, H., \& Botterill, D. (2006).

Past travel experience has been found to influence behavioral intentions among international tourists (Mazursky 1989, Zeithaml 1981, Sonmez, S. F., \& Graefe, A. R. 1998, 1998a). Past experience with similar event or destination moderates tourist's sensitivity to risks they currently face thus reduces the need for thorough information processing while facing a similar event (Barron \& Erev, 2003; Yechiam et al., 2005), According to (Zeithaml 1981), past travel experience able to influence intention to travel because tourism is a services provider which is intangible, purchased simultaneously with production and typically hard to standardize, which tourists' perceived risk is likely to be high. Hence, past experience served as a subjective reference and judgment for tourists before deciding to travel to particular destination. Tourists which had a positive or negative experience travelling to particular destination before will have a tendency to travel or not travel respectively. Past travel experience to specific destinations not only increases the intention to travel there again but also decreases the intention to avoid particularly risky areas (Sonmez, S. F., \& Graefe, A. R. 1998).

In tourism research, culture has been recognized as an important factor in deciding on particular destination. In prior research, several aspect of culture has been studies, which are tourist's national culture, culture of one particular destination, and the distance between the two cultures. Few researchers have studied culture as a destination attribute (O'Leary and Deegan, 2003), and as important factor for travelling to a particular destination (McKercher and Cros, 2003). O'Leary and Deegan (2003) categorized culture as tangible and intangible heritage, which included music, museums, historical places, traditional richness, climate and scenery. Previous research has examined the factors that influence tourist's destination choices, by considering the impact cultural similarity or difference. Some researchers have argued cultural similarity contributes to destination choice (Wong and Kwong, 2003) while the other hand, other researchers have agreed that destination choice is led by cultural differences (McKercher and Cros 2003).

The presence of a direct attack on tourist homeland might affect intention to travel internationally. Tourists who had directly experienced danger or threat might influence their destination choice. Sackett, H., \& Botterill, D. (2006) identified the influence of the proximity of a terrorist attack upon the perceptions of international travel risk and found that perceived risks associated with international travel have increased due to proximity thus affect tourist intention to travel to particular destination. 
The intention to travel is influenced by factors such as demographic and psychographic factors (Rajasenan and Ajitkumar 2004). Psychographic consists of lifestyles and personality values in which lifestyles involved with activities, interests and opinions, while personality include internal and external traits (Abduljalil Sarli and Huam Hon Tat 2011). Lepp, A., \& Gibson, H. (2008) argues that personality traits influence destination choices. Investigation on the utility of the sensation seeking personality trait found that both high and low sensation seekers perceived risk similarly. It is because most sensation seekers are risk taker, loves adventurous activities and prefer risk as a main destination choice. However, this personality traits do influence destination choice because they more likely to travel internationally to regions that are rated as riskier.

Demographic refers as studies of a population based on factors such as age, race, sex, and economic status, level of education, income level and employment. Demographics are used as a factor which influences tourist intention to travel. Floyd, M., \& Pennington-Gray, L. (2004) find that relationship between demographic factors and intention to travel does exist. Result show that young female and not employed or employed part-time use information source before traveling and perceived greater risk and more likely to agree that travel is risky and that is the most important attribute a destination can offer. Meanwhile, an older, employed full time or retired person is less likely to use these information sources and perceived less risk and likely to agree that tourists were not likely to be targets of terrorism.

\section{Factors influencing risk perception among tourist.}

Previous trips at similar or different destination not only influence intention to travel, but also has a direct impact on risk perception. In fact, past experience managed to reduce the level of perceived risks faced by tourists. Tourists who have previous travelling experience tend to have realistic perception about risks than the non-experienced travelers (Mohammad Reza, 2012). In addition, tourist prior experience able to influence tourist's attitude toward travelling at risky destination. It has been found that a greater number of previous trips abroad tend to reduce the perceptions of travel risk and positively affect attitudes toward travel to risky destinations (Sharon Teitler-Regev, Helena Desivilya-Syna, Shosh Shahrabani. 2014). This will result in enhancing the intention to travel to risky destination due to decreasing in tourist perceived risks as attitudes toward travel to risky destinations become more positive.

Roehl and Fesenmaier, (1992) found that psychographic factors affect risk perception level. According to the analysis of the respondents based on the three risk dimensions, three groups of travelers (Risk Neutral group, a Functional Risk group, Place Risk) were identified with different risk perceptions regarding travel. The three risk groups were differed in terms of psychological attributes (the most recent trip taken and the benefits sought from travel as well as basic demographic characteristics). Other researcher, Mohammad Reza, (2012) explored the tourists' perceived risks travelling to Iran and identify whether tourist's past experience with the Islamic destination able to reduce these risks and determine the impact of individual factors on tourists' perceived risks. Result revealed that besides past experience, the respondent's individual characteristics which are gender, nationality, frequency of visits, and purpose of visit have influenced their level of risk perceptions. 
Prior research has examined the influence of the cultural distance between tourists home and host cultures on tourists' perceptions. Lepp and Gibson (2003) found that people received greater perceived risk when they visited less familiar or culturally distant destinations. It is because visitors with different culture may be easy targets for criminals due to their ignorance of local languages, signs and customs and a lack of local support groups (Pizam, Tarlow and Bloom, 1997). If there is little consistency between tourists' expectations and host's attitudes, due to cultural differences, stress, anxiety and uncertainty will be develop, resulting in dissatisfaction (Reisinger and Turner, 1998).

Reisinger, Y., \& Mavondo, F. (2005) investigated the impact of cultural and psychographic factors on perceptions of risk, anxiety, and intentions to travel internationally. Result found that culture, personality and motivation to travel had significant influence on perceptions of risk, anxiety, and safety.

Other researcher also found that travelers from different national cultures have difference degrees of the perceived risk. For example, Seddighi, H.R., Nuttall, M.W., \& Theocharous (2000), agreed that culture background plays a significant role in the determination of the perceptions of risk. The investigation on the cross-cultural differences of the perceptions of travel agents concerning the impact of political instability on tourism shows that cultures do influence risk perception, which in his research, focuses on various types of political instability risk.

Demographic factors also contribute to difference in tourist perceived risks. Reisinger, Y., \& Mavondo, F. (2006) found that beside culture, demographic characteristics has been found contributed to the differences in in perception of risk and safety, anxiety, and intentions to travel among groups of tourists. However, some of the identified differences occur as a result of the respondents' gender and age profile.

\section{Relationship between risk perception and intention to travel}

Tourist's perception on risk will influence their decision whether to travel or not. As the level of risk perception increase, the decision to travel internationally will be changed or modified. For example, Kozak, M., Crotts, J.C., \& Law, R. (2007) investigated the impact of perceived risk on the tendency to travel internationally. It was found that, majority of travelers are more likely to change their travel plans to a destination that has low risk. According to (Sonmez, S. F., \& Graefe, A. R. 1998), perceived risks were found to be a stronger predictor of avoiding regions than of planning to visit them. Besides, the destinations that develop an unsecure reputation also will be substituted by alternative destinations or places that are perceived as safer for them (David Mc.A Baker 2014). Basically, the tourist will change their plans or decision, such as non-booking, cancellation, or evacuation from the risky destinations especially when they feel that particular risk is too high (Mansfeld, 2006).

Risk perception as mediator to the relationships between factors affect intention to travel Mediator variables specify how or why a particular effect or relationship occurs. Risk perception is the process that occurs to create the relationship between past experience, demographics, psychographics, culture and proximity with intention to travel. Based on the conceptual model, it is 
INTERNATIONAL JOURNAL OF ACADEMIC RESEARCH IN BUSINESS AND SOCIAL SCIENCES

Vol. 8, No. 11, Nov, 2018, E-ISSN: 2222-6990 @ 2018 HRMARS

hypothesized that these factors (past experience, demographics, psychographics, culture and proximity) would increase or decrease the perception of risk, which in turn would affect the decision or intention to travel abroad. In this paper, risk perception as mediator explains how these factors may come to be associated with intention to travel. Previous research stated the past experience, demographics, psychographics, culture and proximity influence the tourist perception on risk (Mohammad Reza, 2012; Sharon Teitler-Regev, Helena Desivilya-Syna, Shosh Shahrabani. 2014; Roehl and Fesenmaier, 1992; Lepp and Gibson, 2003; Reisinger \& Mavondo, 2005, 2006; Seddighi, H.R., Nuttall, M.W., \& Theocharous, 2000; Sackett, H., \& Botterill, D. (2006) hence, affect tourist decision to travel internationally (Kozak, M., Crotts, J.C., \& Law, R. 2007; Sonmez, S. F., \& Graefe, A. R. 1998) Alternatives might be stick to the existing plan, modify plan or avoid travelling to particular destination.

\section{CONCEPTUAL FRAMEWORK}

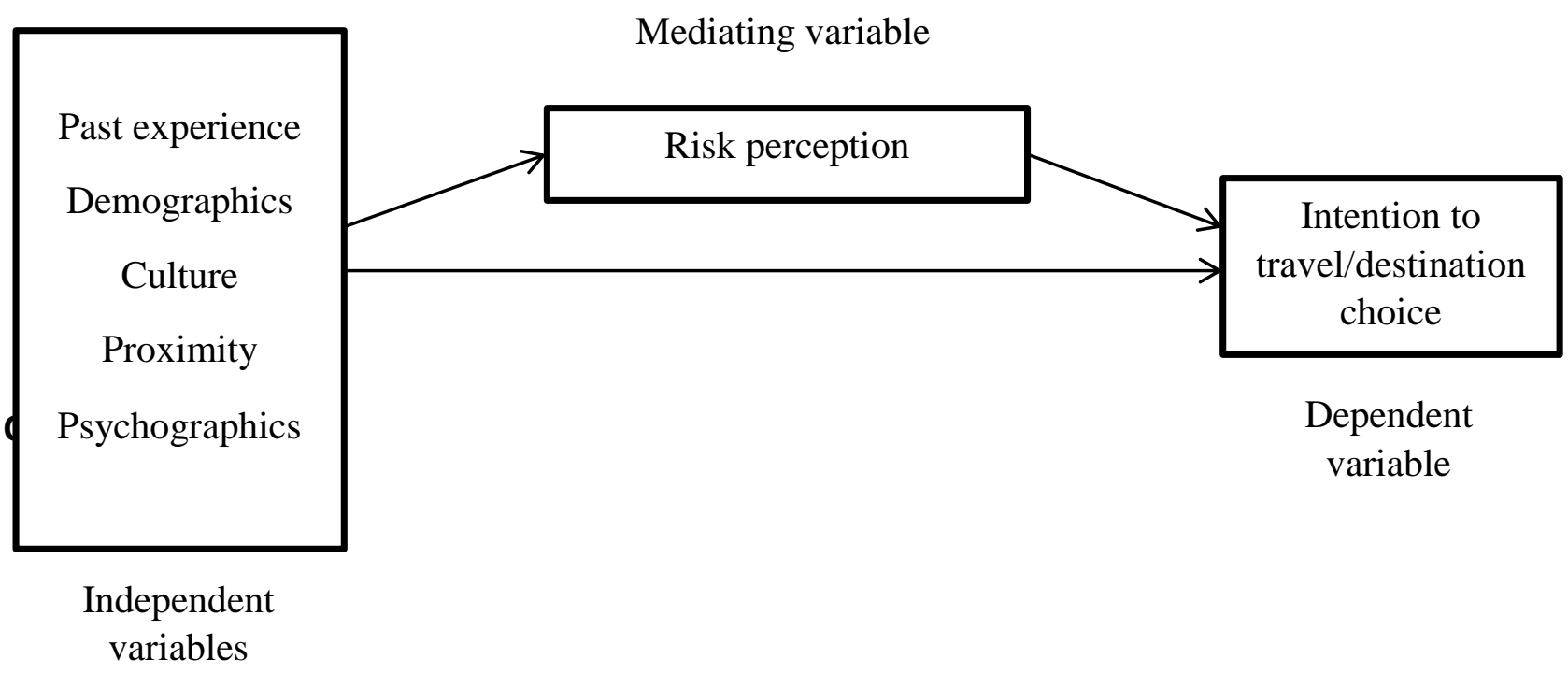

This paper focuses on analyzing the relationship between several factors which influence tourist destination choice by having risk perception as the third variable to be tested. The expected result should describe whether the relationship between variables does exist or not. This paper should be able to contribute knowledge especially to tourist and tourism service operator as guidelines how to manage risks as well as to ensure the sustainability of the business, own life and the industry itself.

\section{REFERENCES}

Barron, G., \& Erev, I. (2003). Small Feedback-based Decisions and their Limited Correspondence to Description based Decisions. Journal of Behavioral Decision Making, (3), 16.

Bauer, R. A. (1960). Consumer behaviour as a risk taking. In R. S. Hancock (Ed.), Dynamic marketing for a changing world (pp. 389-398). Chicago: American Marketing Association. 
INTERNATIONAL JOURNAL OF ACADEMIC RESEARCH IN BUSINESS AND SOCIAL SCIENCES Vol. 8, No. 11, Nov, 2018, E-ISSN: 2222-6990 @ 2018 HRMARS

Brooker, G. (1983) "An Assessment of an Expanded Measure of Perceived Risk." In Advances in Consumer Research, vol. 11, T. C. Kinnear, ed. Provo, UT: Association for Consumer Research, pp. 439-41.

Cheron, E. J., and J R. B. Ritchie (1982). "Leisure Activities and Perceived Risk." Journal of Leisure Research, 14: 139-54.

Baker, David Mc. A (2014) "The Effects of Terrorism on the Travel and Tourism Industry," International Journal of Religious Tourism and Pilgrimage: Vol. 2: Iss. 1, Article 9.

Dholakia, U. (2001). A motivational process model of product involvement and consumer risk perception. European Journal of Marketing, 35(11/12), 1340-1360.

Dowling, G., \& Staelin, R. (1994). A model of perceived risk and intended risk handling activity. Journal of Consumer Research, 21(1), 119-134.

Floyd, M., \& Pennington-Gray, L. (2004). Profiling risk perceptions of tourists. Annals of Tourism Research, 31(4), 1051- 1054.

Helena Desivilya Sharon Teitler-Regev Shosh Shahrabani. (2015),"The effects of conflict on risk perception and travelling intention of young tourists", EuroMed Journal of Business, Vol. 10 Iss 1 pp. $118-130$

Jacoby, J., \& Kaplan, L. (1972). The components of perceived risk. In Proceedings of the third Annual Conference of the association for consumer research (pp. 382-393). Ann Arbor, MI: Association for Consumer Research.

Kaplan, L. B., G. J. Szybillo, and J. Jacoby (1974). "Components of Perceived Risk in Product Purchase: A Cross-Validation. Journal of Applied Psychology, 59: 287-91.

Kerzner, H. (2001). Project management: a systems approach to planning, scheduling, and controlling. 7th ed. New York: Wiley.

Kozak, M., Crotts, J.C., \& Law, R. (2007). The impact of the perception of risk on international travelers. International Journal of Tourism Research, 9, 233-242.

Lepp And Gibson (2003) , "Tourist Roles, Perceived Risk And International Tourism", Annals of Tourism Research, Vol. 30, No. 3, Pp. 606-624, 2003

Lepp, A., \& Gibson, H. (2008). Sensation seeking and tourism: Tourist role, perception of risk and destination choice. Tourism Management, 29(4), 740-750.

Mansfeld, Y., 2006. The Role of Security Information in Tourism Crisis Management: The Missing Link. In: Masfeld, Y. \& Pizam, A. (eds.) Tourism, security and safety: from the theory to practice. Butterworth-Heinemann.

Mazursky, D. (1989). "Past Experience and Future Tourism Decisions." Annals of Tourism Research, 16 (3): 333-44.

McKercher, B., and Cros, H. D., 2003. Testing a cultural tourism typology. The International Journal of Tourism Research, 5 (1), 45-58.

Mohammad Reza Jalilvand Neda Samiei, (2012),"Perceived risks in travelling to the Islamic Republic of Iran", Journal of Islamic Marketing, Vol. 3 Iss 2 pp. 175 - 189

Murray, K., \& Schlacter, J. (1990). The impact of services versus goods on consumers' assessment of perceived risk and variability. Journal of the Academy of Marketing Science, 18(1), 51-65.

O'Leary, S. and Deegan. J. (2003). People, pace, place: Qualitative and quantitative images of Ireland as a tourism destination in France. Journal of vacation marketing, 9 (3), 213-226. 
Rajasenan, D. and Ajitkumar, M.K. (2004). Demographic, Psychographic and Lifestyle Characteristics of Foreign Tourists: An Exploratory study of Kerala, India. Tourism Recreational Research Vol. 29(3), pp.51-59.

Reisinger, Y., \& Mavondo, F. (2005).Travel Anxiety and Intentions to Travel Internationally: Implications of Travel Risk Perception. Journal of Travel Research, Vol. 43, February 2005, 212-225. Reisinger, Y., \& Mavondo, F. (2006). Cultural differences in travel risk perception. Journal of Travel \& Tourism Marketing, 12(1), 13-31.

Sackett, H., \& Botterill, D. (2006). Perception of international travel risk: an exploratory study of the influence of proximity to terrorist attack. E-review of tourism Research, 4(2), 44-49.

Seddighi, H.R., Nuttall, M.W., \& Theocharous, A.L. (2000). Does cultural background of tourists influence the destination choice? An empirical study with special reference to political instability. Tourism Management, 22(2), 181-191.

Wesley S. Roehl and Daniel R. Fesenmaier, (1992), "Risk Perceptions and Pleasure Travel: An Exploratory Analysis", Journal of Travel Research 30: 17

Sonmez, S. F., \& Graefe, A. R. (1998). Determining future travel behavior from past travel experience and perceptions of risk and safety. Journal of Travel Research, 37(2), 172-177

Sönmez, S. \& Graefe, A.R. (1998a). Influence of terrorism risk on foreign tourism decisions. Annals of Tourism Research, 25, 112-144.

Stone, R. N., \& Grønhaug, K. (1993). Perceived risk : Further considerations for the marketing discipline. European Journal of Marketing, 27(3), 39-50.

Sweeney, J., Soutar, G., \& Johnson, W. (1999). The role of perceived risk in the quality-value relationship: a study in a retail environment. Journal of Retailing, 75(1), 77-105.

Wong, C.K.S., and Kwong, W.Y.Y., 2004. Outbound tourists' selection criteria for choosing all-inclusive package tours. Tourism Management, 25 (5), 581-592.

Yechiam, E., Barron, G., \& Erev, I. (2005). The Role of Personal Experience in Contributing to Different Patterns of Response to Rare Terrorist Attacks. Journal of Conflict Resolution, (3), 49.

Zeithaml, V. A. (1981). "How Consumer Evaluation Processes Differ Between Goods and Services." In Marketing of Services J. H. Donnelly and W. R. George, eds. Chicago: American Marketing Association, pp. 186-90. 